\title{
STUDYING THE HUMAN SCALE AND PROPORTIONALITY OF MOSQUE BUILDINGS: SOME SELECTED CASE STUDIES IN ERBIL CITY
}

Received July 20th 2018 | Accepted September 9th 2018 | Available online June 30th 2019 |

DOI http://dx. doi.org/10.18860/jia.v5i3.5304

\section{Faris Ali Mustofa}

Department of Architecture,

College of Engineering, Salahaddin University

Erbil, Kurdistan Region, Iraq

Department of Architecture, Faculty of Engineering Ishik University

Erbil, Kurdistan Region, Iraq

farisyali@yahoo.com

\section{Saya Jamal Rashid}

Department of Architecture,

College of Engineering, Salahaddin University

Erbil, Kurdistan Region, Iraq

\begin{abstract}
Human scale and proportion have an important role in building design as they provide and create aesthetics and sense of place. In architecture, the human scale and proportion are based on the dimensions and proportions of the human body. The mosque is an important institution of Islam and is considered as a symbol of Islamic architecture. Also, it is a place of spiritual connection with God. This study aimed at addressing whether the human scale and proportionality have been used in mosques in the past and present. The objective of this research is to show if mosques in Erbil city built in different periods were concentrated on human scale and proportion to achieve aesthetic and comfort inside its prayer halls. To achieve it, three cases (the Great Mosque of Erbil Citadel, Rashad Mufty Mosque, and Madina Mnawara Mosque) were selected. The golden ratio was used as a technique method to measure and to see if the human scale and proportion were applied. From the three selected mosques, results show that none of them used the golden ratio completely in their designs. The highest value of golden ratio was achieved in the prayer hall of Rashad Mufty mosque with $(82 \%)$ and the Great Mosque of Erbil citadel with (74\%) consequently, while only $61 \%$ of the golden ratio was achieved in Madina Mnawara mosque. This study prompts the new generation of architects in Erbil city to consider human scale and proportionality through the application of a certain method, such as the golden ratio in the design of buildings in general and mosque buildings in particular.
\end{abstract}

KEYWORDS:

Human Scale; Proportion; Golden Ratio; Mosque Building; Erbil City

\section{INTRODUCTION}

The relationship between proportion, nature, and architecture is important to understand because human beings are closely observing nature since their existence. The human has started learning from nature, and they have found that nature has geometric proportions in all its creation, such as human, animals, and plants. Proportions were a very important tool used for aesthetic of building in ancient civilization [1]. In general it is defined as a process for comparing or paralleling with a steady source or criteria that been divided into three concepts: the mechanical scale refers to the comparison of the size of the objects associated with the standard constants; visual scale, which is proportional to other elements such as the fixed size, and the human scale [2] [3].

Scale and proportion play very important roles in architecture. Proportion refers to the proper and harmonious relationship of one part to another or the whole, while scale refers to the size of something compared to a reference standard or the size of something else (like a human being) [4][5]. Many researchers studied the role of human scales in the building design that effect on aesthetics and human's feeling comfortable. They used the golden section and modular as a method to find the proportion between two numbers. This ratio could have quantitative and qualitative meaning attached to it. A mathematician might be interested in a quantitative aspect more, but architects are more interested in the qualitative aspect of this ratio. The quantitative aspect could be called as "Proportion as a ratio" and qualitative aspect as "Proportion as beauty" [6].

In line with this context, there is an urgent need to understand the importance of geometric proportion in the architectural design process. Since the proportion system has lost its significance due to many more multiple design issues in the modern context of contemporary architecture in general and Islamic architec- 
ture in specific [7][8]. Now architects are more concerned about space utilization, energy issues, sustainable principle, form-oriented buildings, structural design, etc. This led to forget the essence of architecture, which lies in its aesthetic, without it, buildings are just machines [9].

This study seeks to ascertain whether the mosques built at different periods in the city of Erbil applied the concept of the golden ratio in their dimensions, forms, and proportions, specifically in the main prayer hall. Such a study may serve local architects to adopt this concept in dealing with proportionality and human scale in their designs in general, and mosque buildings in particular as this approach offers additional aesthetic value to the building and provides psychological comfort and sense of place for the worshipers at the same time.

\section{PREVIOUS RELATED STUDIES}

Gangwar [1] in his study has used the golden ratio as a method to measure the elements of the building to find a relation between geometry nature and architecture. Boussora and Mazouz [10] examined earlier archaeological theories about the Great Mosque at Kairouan as a case study and determined the geometric constructions for the golden section and apply these constructions to the plan of the Mosque. In the same way, Evita and Josephine [11] studied the aesthetic value as the composition (principal mass, subordinate masses, links, appendages) of the building geometry shapes and forms in relation with the building function. They found out that the aesthetic value of structures affects the architectural theory rules, and it's essential for producing a good design.

However, Ramzi and Muffeq [2] aimed in their study to classify the structure according to the relation with the human scale in Islamic architecture. They showed that to determine the mechanisms adopted by Muslim architect is to accomplish the humanitarian scale through investing structure. Dabbour [12] studied the analysis of geometric principles and design features of traditional Islamic patterns involving geometric proportion analysis. He described in his study the mixtures of Islamic patterns from the perspectives of Islamic cosmology, philosophy, and metaphysics of geometry, which can be seen as a principle of geometric and proportional design with high accuracy and great precision [13].

Dahar and Alipour [14] analyzed the Sheik Lotfollah Mosque in Isfahan to discover that the Golden Section and geometrical techniques were used in this mosque to create a balance between the components of the structure. Moreover, Jamil [15] has taken the Shah Faisal Mosque in Pakistan as a modern case study. The study discusses the development of innovative architectural and design elements of the mosque and its benefit to the various functions in terms of space planning, proportion, and aesthetics. Baharudin and Ismail [16] described the design of communal mosque found in Muslim and non-Muslim countries to understand on how these mosques are developed to fulfil the needs of the Muslim community and create a sustainable environment by using comparative studies.

\section{RESEARCH PROBLEM AND AIM}

Historically, the human scale had an essential role in the design of buildings; its role and importance are disappearing in a modern context. Locally, most of the new generation of architects did not know about these proportion systems and its role in other complicated design issues, and also did not pay enough attention and focusing on the design of buildings in regards of proportional beauty. Accordingly, this paper aims to test Erbil mosques built in different periods to see if the human scale and proportionality have been considered to obtain aesthetic and sense of place inside the prayer hall in these mosques by analyzing its floor plans via Golden Ratio technique.

\section{RESEARCH QUESTION}

To clarify and solve the research problem in pursuit of the research objectives, the current paper raises a fundamental research question in an attempt to find a convincing answer:

Are the mosques built in Erbil city at different periods applying specific method concerning the human scale and proportionality inside its prayer hall?

\section{METHOD}

To know if the human scale and proportion have been considered in mosques built in Erbil city, Golden Ratio was used as a methodology. The steps of applying this method have been described in previous sections. In this study, three mosques in Erbil city built in different periods were selected as cases of study. These mosques are (the Great Mosque of Erbil Citadel, Rashad Mufty Mosque, and Madina Mnawara Mosque) (Figure 5). The method of analysis covers the floor plan of mosques focusing on the prayer hall of these mosques. Each case study was described, then the Golden Ratio was applied and analyzed on the dimensions and shapes of the prayer hall.

Table 1. Selected mosques in Erbil city as cases of study (authors).

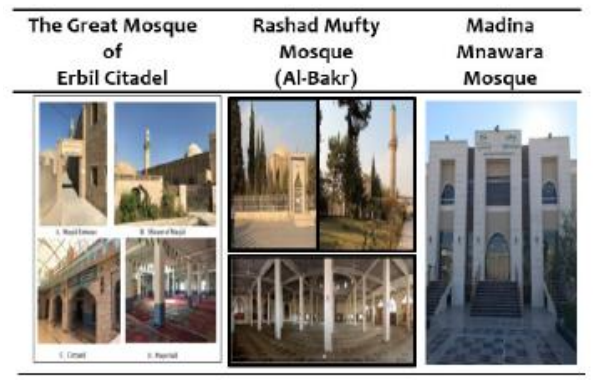

GOLDEN RATIO METHOD

There are varieties in definitions of the golden ratio [17]. "Father of Geometry" is the nickname of 
Euclid who was the first one who discussed the Golden Ratio definition. He said that "A straight line to have been cut in extreme and mean ratio when as the whole line is to the greater segment so is the greater to the less". Golden ratio is a ratio between sections or dimension of one element. The ratio can be shown by the equation, as shown in (Figure 1). Golden section, divine proportion, golden proportion, and golden mean are other terms for it. The ratio equal to Phi $[\Phi]=$ 1.618033988749895 [1][12][18].

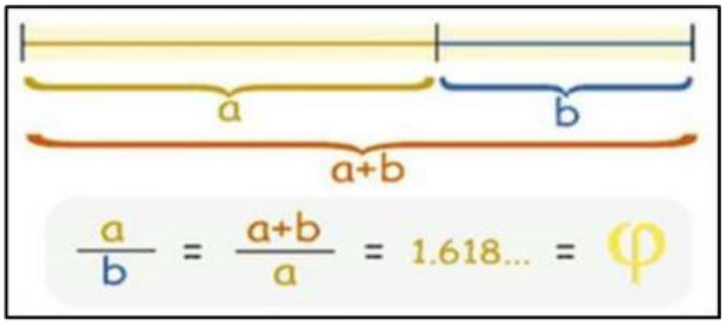

Figure 1. Golden Ratio through line segment [1].

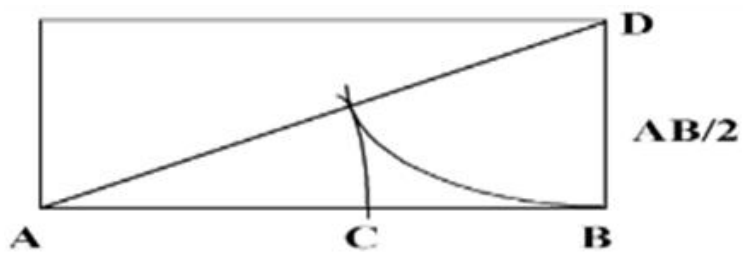

Figure 2. Construction of the golden section by division [1]

[10]

The second method consists of generating a golden rectangle from a square through the following steps (Figure3):

- Draw a square having $A B$ as a side;

- Divide AB in half;

- Draw a diagonal from the middle of the side $A B$ to the opposite corner. Swing this diagonal till it cuts the line $A B$ at $C$.

The golden rectangle generated will have $A C$ as its length; its width will be equal to $A B$. Following the same method, a golden ratio progression will be obtained across the entire line $A B$. We will then have:

$A C: A B:: A B: B C:: B C: C D:: B D: B C$

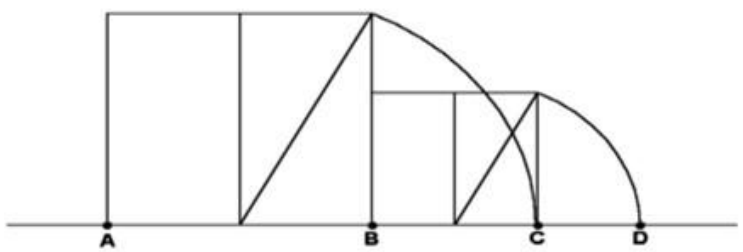

Figure 3. Construction of the golden section by extension [12]

\section{CASE STUDIES THE GREAT MOSQUE OF ERBIL CITADEL}

It is located in the centre of Erbil Citadel next to the public (hamam) building. The date of built is not clear; some historians date back its history to the Ottoman Empire, and others linked its date with the date of built mimber at (1719-1132) A.D [19]. The Minaret located in the North West of the mosque. The mosque has an irregular plan, it dimensions around $(51.4 \mathrm{~m} \times 31.98 \mathrm{~m})$ with the area around $1452 \mathrm{~m}^{2}$. The mosque consists of; two entrances, cour It is located in the center of Erbil Citadel next to the public (hamam) building. The date of built is not clear, some historians date back its history to the Ottoman Empire and others linked its date with the date of built mimber at (1719-1132) A.D. The Minaret located in the North West of the mosque. The mosque has an irregular plan, it dimensions around $(51.4 \mathrm{~m} \times 31.98 \mathrm{~m})$ with the area around $1452 \mathrm{~m}^{2}$. The mosque consists of; two entrances, courtyard, women hall, main prayer hall, studying room, WC, and Imam's room (Figure 6). The area of the prayer hall is around $700 \mathrm{~m}^{2}$ with the dimensions $(31.98 \mathrm{mx} 22.1 \mathrm{~m})$ [20]. $\mathrm{t}$ yard, women hall, main prayer hall, studying room, WC, and Imam's room (Figure 6). The area of the prayer hall is around $700 \mathrm{~m}^{2}$ with the dimensions $(31.98 \mathrm{mx} 22.1 \mathrm{~m})$ [20].

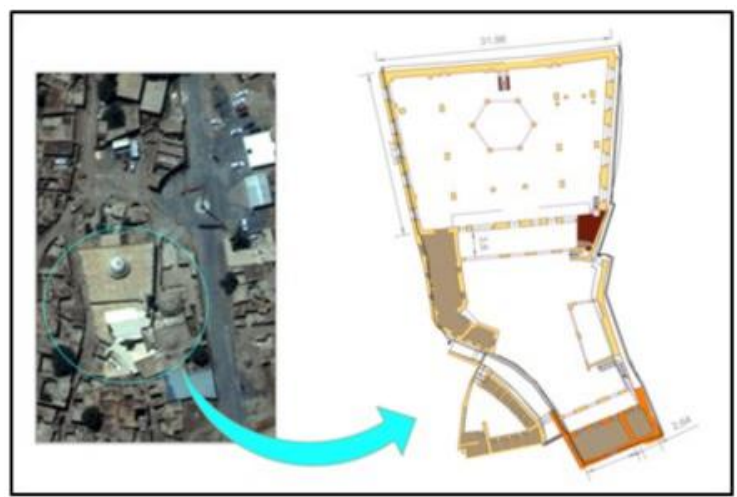

Figure 4. Plan of the great mosque of Erbil Citadel (authors).

\section{RASHAD MUFTY MOSQUE (AL-BAKR MOSQUE)}

It was built in 1981 and located on Kirkuk road near the College of Agriculture and College of Education. Plot area is about $6000 \mathrm{~m}^{2}$, with dimensions $(78.5 \mathrm{~m} \times 78 \mathrm{~m})$ as shown in (Figure 7 ). The mosque contains main prayer hall, women prayer hall, portico, dome, minaret, fountain \& courtyard, W.C, studying room, and green area. The area of the prayer hall is around $1500 \mathrm{~m}^{2}$ with dimensions (35.60 x 47.60) meters [20]. 


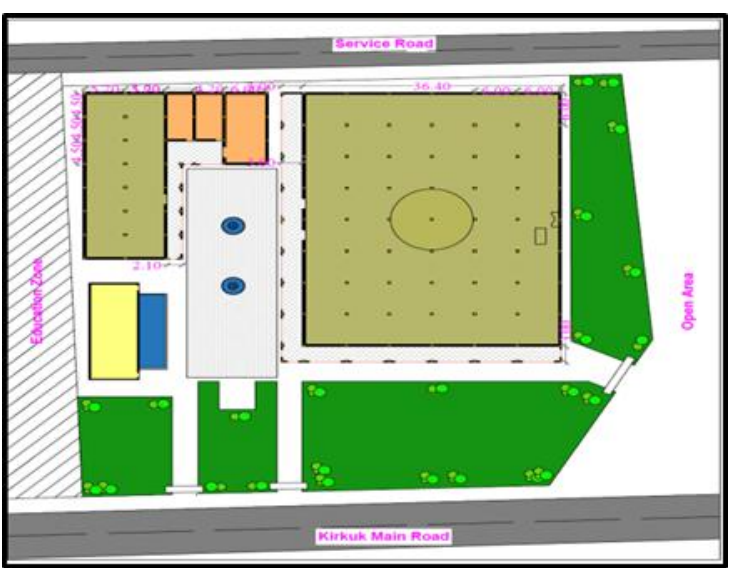

Figure 5. Site plan of Rashad Mufty Mosque [20].

\section{MADINA MNAWAR MOSQUE}

Madina Mnawara Mosque was built in 2010 and located on Koya road-new Hawler district. Building area about $4000 \mathrm{~m}^{2}$ with dimensions $(78 \mathrm{~m} \times 53 \mathrm{~m})$. It includes a prayer hall, women prayer hall, entrance, shaded places, basement, W.C, studying room, and green area (Figure 8$)$. The prayer hall's area is around $1000 \mathrm{~m}^{2}$ with dimensions $(32.2 \mathrm{~m} \times 32.2 \mathrm{~m})$.

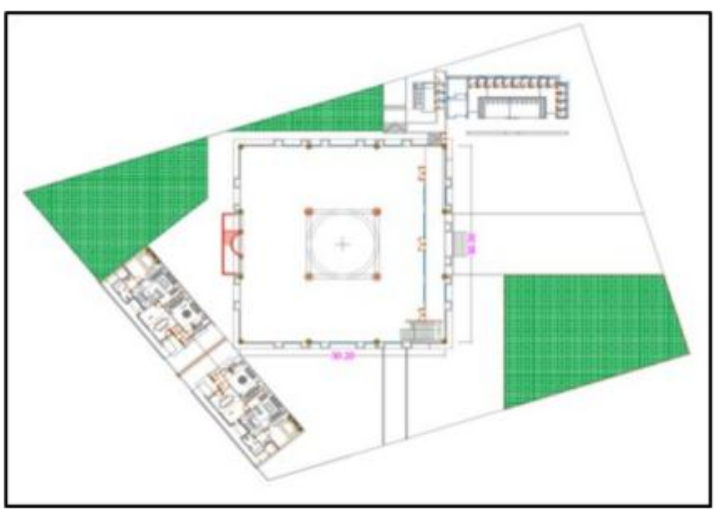

Figure 6. Site plan of Madina Mnawara Mosque (authors).

\section{FLOOR PLAN ANALYSIS APPLYING GOLDEN RATIO}

This research has focused on the prayer hall of the selected mosques to examine Golden Ratio with a golden rectangle from a square, applied through specific steps as follows:

- Determine dimensions of prayer hall;

- Draw the square of golden ratio which size of square determined by length of the plan;

- Divide the length of the prayer hall in half;

- Draw a diagonal from the middle of length to the opposite corner;

- Swing this diagonal till it intersects the line.

\section{THE GREAT MOSQUE OF ERBIL CITADEL}

Initially, the dimensions of the prayer hall are determined, then the square of Golden Ratio is applied. This mosque has an irregular plan, so to use the square of golden ratio; this requires fitting the plan to the rectangle of the golden ratio, as shown in (Figure 9).

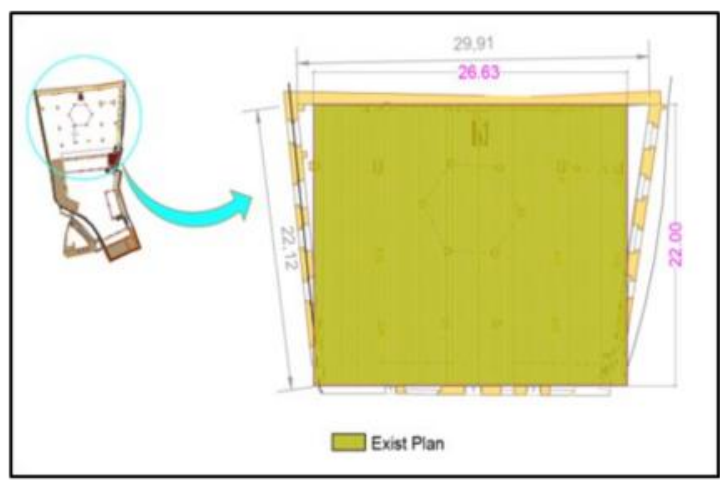

Figure 7. The actual dimensions of the prayer hall in the great mosque of Erbil Citadel (authors).

The average dimensions of the plan are taken as a rectangle to apply the square of Golden Ratio through specific steps as follows:

- The length of $A B$ determined according to the length of prayer hall;

- A square is drawn, having $A B$ as its side;

- Then, a circle is struck from the middle of $A B$ to the opposite corner of the square;

- This diagonal will be rotated on the line $A B$;

- The point $C$, resulting from the intersection of the diagonal square and the line $A B$, will be rotated on the adjacent side of $A B ; C$ results from this intersection;

- A golden rectangle has $A B$ as its length and $B C$ as its width (Figure 10).

This analysis was arranged with the numerical analysis of some major dimensions as follows:

- The dimension of $A B$ (prayer hall length) is $26.63 \mathrm{~m}$.

- The dimension of BD (prayer hall width) is $22 \mathrm{~m}$.

- The dimension of BC (typical width) $16.44 \mathrm{~m}$.

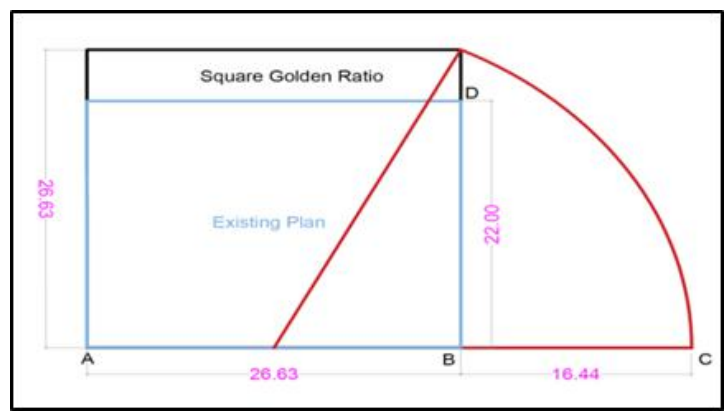

Figure 8. Applying Golden Ratio on the prayer hall plan in the great mosque of Erbil Citadel (authors) 


\section{RASHAD MUFTY MOSQUE}

The dimensions of the prayer hall in this mosque are $(47.60 \mathrm{~m} \times 35.60 \mathrm{~m})$. Based on the length of the prayer hall, which is $(47.60 \mathrm{~m})$, the golden square will be drawn (Figure 11).

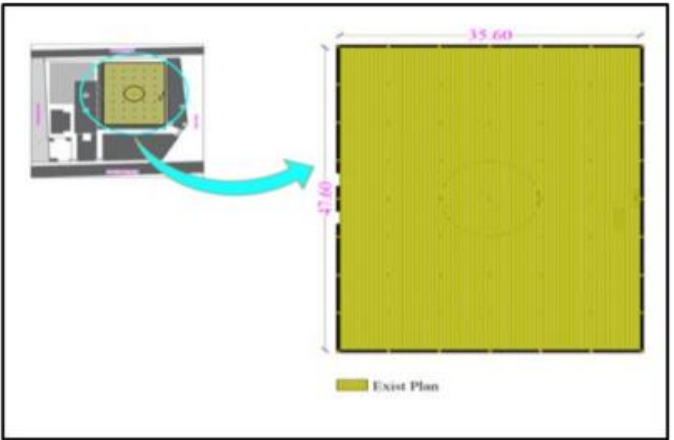

Figure 9. The actual dimensions of the prayer hall in Rashad Mufty mosque (authors).

The following steps were applied to check the golden ratio of the plan:

- The length of the prayer hall is represented with $A B$.

- Draw the golden square on a plan which dimension based on $A B$.

- Split $A B$ to half

- Then, a circle is struck from the middle of $A B$ to the opposite corner of the square.

- This diagonal will be rotated on the line $A B$.

- The point $C$, resulting from the intersection of the diagonal square and the line $A B$, will be rotated on the adjacent side of $A B ; C$ results from this intersection.

- A golden rectangle is having $A B$ as its length and $B C$ as its width is obtained (Figure 12). This analysis was arranged with the numerical analysis of some major dimensions as follows:

- The dimension of $A B$ (prayer hall length) about $47.60 \mathrm{~m}$.

- The dimension of BD (prayer hall width) about $35.6 \mathrm{~m}$.

- The dimension of BC (typical width) $29.40 \mathrm{~m}$.

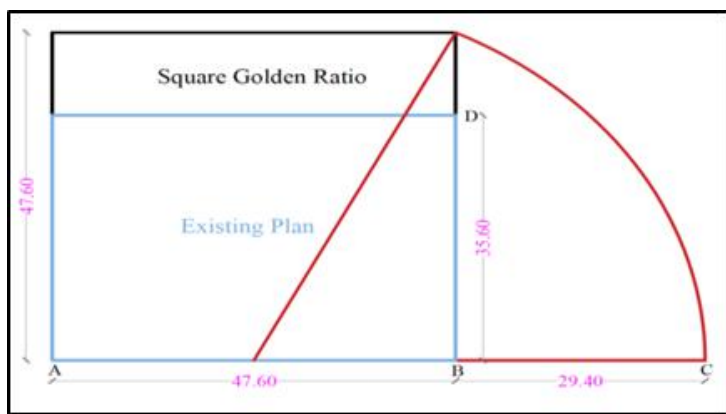

Figure 10. Applying Golden Ratio on the prayer hall plan in Rashad Mufty mosque of Erbil Citadel (authors).

\section{MADINA MNAWARA MOSQUE}

The prayer hall in this mosque has a square shape with dimensions (30.20m x 30.20m). Golden Square was applied to determine the typical dimensions (Figure 13).

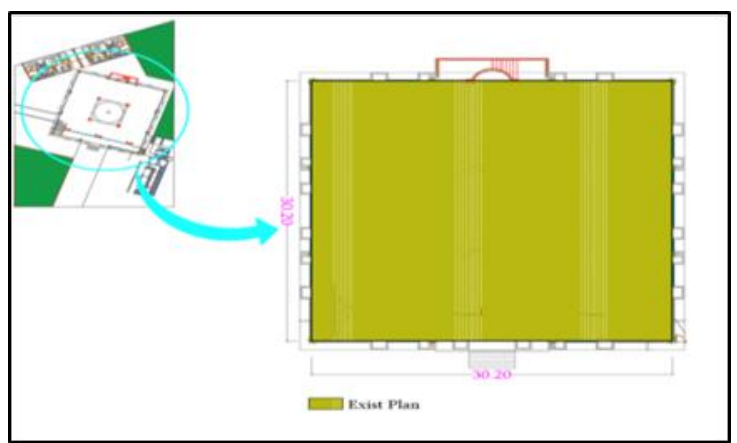

Figure 11. The actual dimensions of the prayer hall in Madina Mnawara Mosque (authors).

To test the golden ratio of the plan, the following steps will be taken:

- The length of the prayer hall is represented by $A B$

- The Golden Ratio is applied because the prayer hall is square

- Divide $A B$ to half.

- Then, a circle is struck from the middle of $A B$ to the opposite corner of the square.

- This diagonal will be rotated on the line AB.

- The point $C$, resulting from the intersection of the diagonal square and the line $A B$ will be rotated on the adjacent side of $A B ; C$ results from this intersection.

- A golden rectangle is having $A B$ as its length and $B C$ as its width is obtained (Figure 14).

This analysis was arranged with the numerical analysis of some major dimensions as follows:

- The dimension of $A B$ (prayer hall length) about $30.20 \mathrm{~m}$.

- The dimension of BD (prayer hall width) about $30.20 \mathrm{~m}$.

- The dimension of BC (typical width) is $18.66 \mathrm{~m}$.

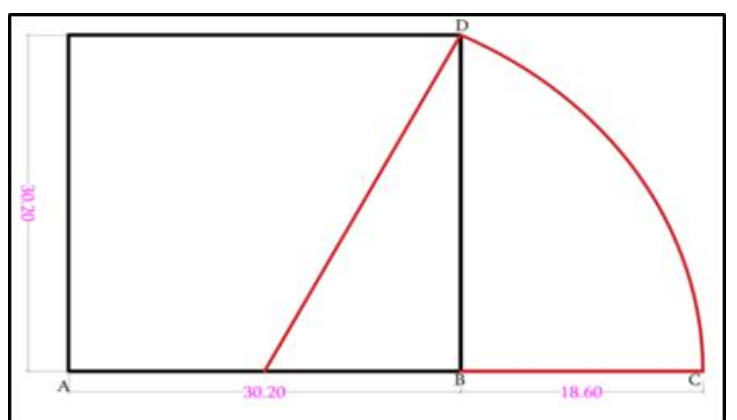

Figure 12. Applying Golden Ratio on the prayer hall plan in Madina Mnawara mosque of Erbil Citadel (authors). 


\section{RESULTS AND DISCUSSION}

According to the process of analyzing the implementation of the Golden Ratio strategy on the selected cases of mosques in the city of Erbil, the following results were achieved:

- Regarding the great mosque of Erbil citadel, the results indicated that the dimension of length $A B$ is $(26.63 \mathrm{~m})$ and the width $B D$ is $(22.00 \mathrm{~m})$ equal to a ratio (1.210). This means that it does not achieve the value of the Golden Ratio (1.618). To achieve the golden ratio of the plan, the dimensions of the prayer hall in this mosque should be $(26.63 \mathrm{~m} x$ $16.44 \mathrm{~m}$ ) as shown in (Figure 15).

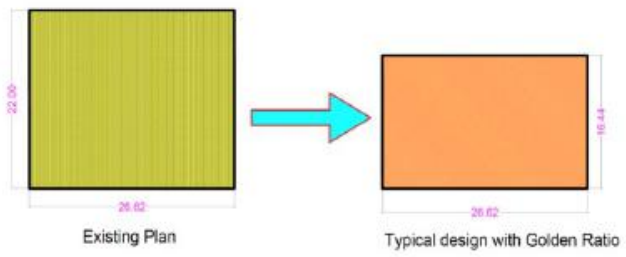

Figure 13. Existing plan and typical plan with Golden Ratio of the prayer hall in the great mosque of Erbil citadel (authors).

- As for the results related to the prayer hall in Rashad Mufty Mosque, the length $A B$ is $(47.60 \mathrm{~m})$, and the width $B D$ is (35.60) which achieved the ratio (1.337). This means that it does not achieve the value of the Golden Ratio (1.618). For achieving the typical golden ratio, the dimensions of the prayer hall should be $(47.60 m * 29.40 m)$ as shown in (Figure 16).

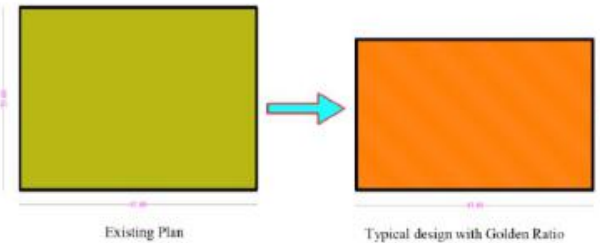

Figure 14. Existing plan and typical plan with Golden Ratio of the prayer hall Rashad Mufty mosque of Erbil citadel (authors).

- About Madina Mnawara Mosque, the results indicated that the dimensions of $A B$ and $B D$ are $(30.20$ $\mathrm{m})$, achieving the ratio (1), which means that it does not attain the value of the Golden Ratio (1.618). The typical dimensions of the prayer hall in this mosque should be $(30.20 \mathrm{~m} * 18.66 \mathrm{~m})$ to achieve the golden ratio (Figure 17).

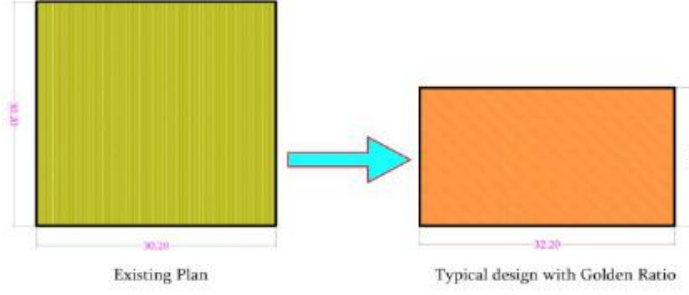

Figure 15. Existing plan and typical plan with Golden Ratio of the prayer hall in Madina Mnawara mosque (authors).

Table 1 shows the comparison between the existing plan of the prayer hall of each case and the typical plan with applying the Golden Ratio. The prayer hall of the great mosque of Erbil citadel achieved 74\% of Golden Ratio, while Rashad Mufty mosque reached about $82 \%$ of Golden Ratio. As for the prayer hall in the mosque of Medina Mnawara, it has achieved $61 \%$ of the value of the golden ratio, recording the lowest value among the three cases.

Table 2. Percentages of golden ratio achieved from the existing dimensions of the prayer hall in three selected mosques (authors).

\begin{tabular}{lccc}
\hline \multicolumn{1}{c}{$\begin{array}{c}\text { Case } \\
\text { Studies }\end{array}$} & $\begin{array}{c}\text { Actual } \\
\text { Dimensions }\end{array}$ & $\begin{array}{c}\text { Golden } \\
\text { Ratio }\end{array}$ & $\begin{array}{c}\text { Golden Ratio } \\
\%\end{array}$ \\
\hline $\begin{array}{l}\text { The Great } \\
\text { Mosque of } \\
\text { Erbil Citadel }\end{array}$ & $\begin{array}{c}(26.63 \times 22.00) \\
\mathrm{m}\end{array}$ & $\mathbf{1 . 2 1 0}$ & 74 \\
$\begin{array}{l}\text { Rashad Mufty } \\
\text { Mosque }\end{array}$ & $\begin{array}{c}(47.60 \times 35.60) \\
\mathrm{m}\end{array}$ & $\mathbf{1 . 3 3 7}$ & 82 \\
$\begin{array}{l}\text { Madina Mna- } \\
\text { wara } \\
\text { Mosque }\end{array}$ & $\begin{array}{c}(30.20 \times 30.20) \\
\mathrm{m}\end{array}$ & 1 & \\
\hline
\end{tabular}

The results revealed that none of the three cases achieved the golden ratio. This proves that the design of prayer halls in the mentioned mosques did not take into account the achievement of the Golden Ratio as a way to obtain the aesthetic and psychological comfort of prayers and worshipers.

Table 2 presents the typical dimensions of the prayer hall in the selected mosques based on Golden Ratio, where the suggested sizes for the great mosque of Erbil citadel are $(26.63 \times 16.44) \mathrm{m},(47.60 \times 29.40) \mathrm{m}$ for Rashad Mufty mosque, and (30.20x18.66) $\mathrm{m}$ for Madina Mnawara mosque. 
Table 3. Typical dimensions of the prayer halls for three selected mosques to achieve the golden ratio (authors).

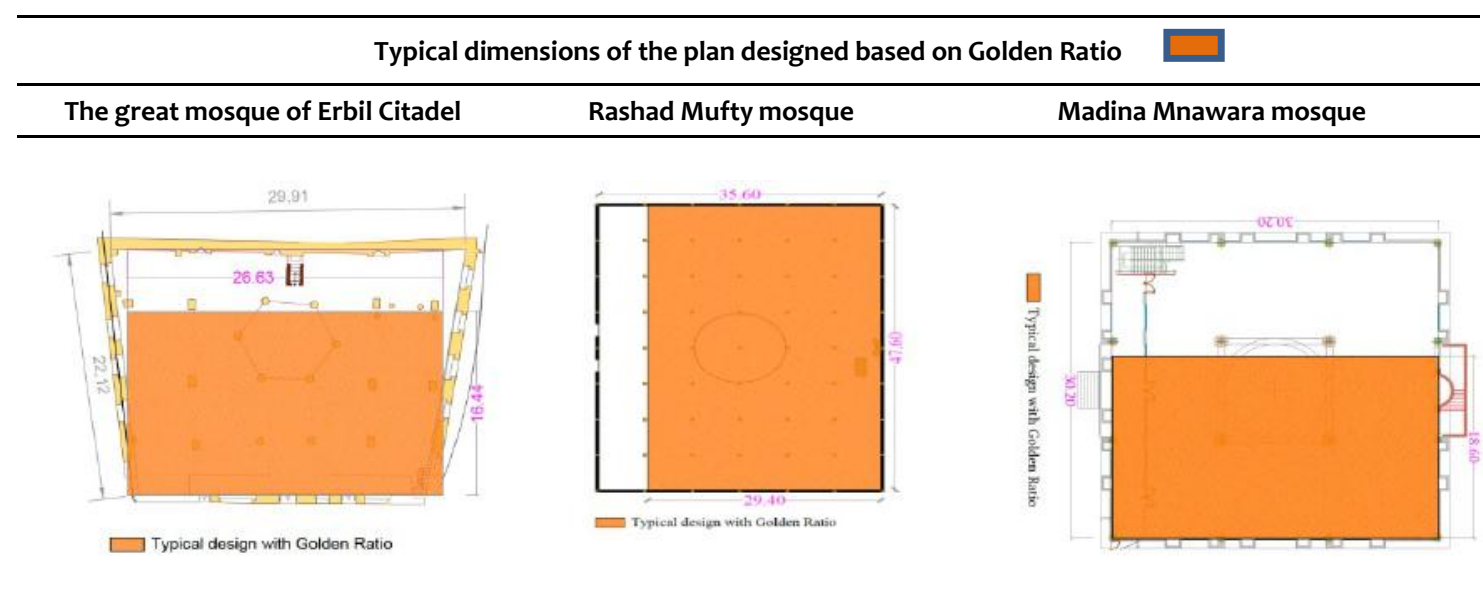

\section{CONCLUSION}

Human scale and proportion have a significant role in mosque design specifically at the level of the interior as they create aesthetically, comfortable spaces, and providing a sense of place which in turn contributes to the creation of a unique place for a spiritual connection to God. The feeling of place not only leads to coordination and function appropriate to the space of architecture and human but also causes the safety, enjoyment and emotional awareness of people and helps in identifying people and their sense of belonging to the place.

A mosque is regularly used at least five times a day for praying, and for weekly events such as Jumu'ah (Friday prayers). This requires careful handling of the interior spaces of the mosque, especially the main prayer hall. The deliberate interaction with the interior space of mosques built based on human scale and proportionality creates a deep feeling for the worshiper and adds aesthetic and psychological comfort to him at the same time. When humans become accustomed to space over time and acquire a sense of belonging to it, this space becomes precious to them for their sense of intimacy and tenderness to that space.

The results showed that mosques selected as cases of the study were built at different periods in Erbil city didn't take into consideration a specific method as a design strategy in dealing with the dimensions of the main prayer hall. The research finds that the negligence of this aspect by the architects in the past and present leads to the creation of spaces that do not meet the aesthetic, psychological comfort, and sense of place of worshipers and devotees.

The golden ratio as a design principle provides the architects with a unique solution to deal with the dimensions of the internal spaces of the mosques in general and the prayer hall in particular. The current study prompts the new generation of architects and interior designers in Erbil city to take into account the human scale and proportion in mosque buildings through the application of a particular method, such as golden ratio in their designs and projects.

\section{REFERENCES}

[1] G. Gangwar, "Principles and Applications of Geometric Proportions in Architectural Design," J. Civ. Eng. Environ. Technol., vol. 4, no. 3, pp. 171-176, 2017.

[2] H. Ramzi and M. Muffeq, "Structure as a Tool of Achieving Human Scale in the Islamic Architecture," in Proceedings of the International Conference on Transport, Civil, Architecture and Environment engineering (ICTCAEE'2012), 2012, pp. 72-78.

[3] N. A. Salingaros, "Architecture, Patterns, and Mathematics," Nexus Netw. J., vol. 1, no. 1-2, pp. 75-86, Jun. 1999.

[4] F. D. K. Ching, Architecture, Form, Space and Order, Fourth. Hoboken, New Jersey: John Wiley and Sons, Inc, 2015.

[5] J.-H. Park, "Rudolph M. SchindlerProportion, Scale and the 'Row,"' Nexus Netw. J., vol. 5, no. 2, pp. 65-72, Oct. 2003.

[6] M. A. Cohen, "Introduction: Two Kinds of Proportion,” Archit. Hist., vol. 2, no. 1, pp. 1-25, Jun. 2014.

[7] M. Hejazi, "Geometry in nature and Persian architecture," Build. Environ., vol. 40, no. 10, pp. 1413-1427, Oct. 2005.

[8] P. J. Lu and P. J. Steinhardt, "Decagonal and Quasi-Crystalline Tilings in Medieval Islamic Architecture," Science (80-. )., vol. 315, no. 5815, pp. 1106-1110, Feb. 2007.

[9] E. Dizany, "Finding the Patterns of Indian Mosques Architecture," Iran. Sci. J. NAZAR Res. Cent. Art, Archit. Urban., vol. 14, no. 48, pp. 7382, 2017.

[10] K. Boussora and S. Mazouz, "The use of the Golden Section in the Great Mosque at Kairouan," Nexus Netw. J., vol. 6, no. 1, pp. 7-16, 2004.

[11] E. Evita and C. Josephine, "The Study of Geometric Forms, Proportion and Scale of Herit- 
age Buildings Due to Architectural Theory," in Proceedings of the 8th International Conference on Architecture Research and Design $(A R+D C)$, 2016, pp. 264-272.

[12] L. M. Dabbour, "Geometric Proportions: The Underlying Structure of Design Process for Islamic Geometric Patterns," Front. Archit. Res., vol. 1, no. 4, pp. 380-391, 2012.

[13] J. M. Nejad and A. S. H. Abad, "Hidden geometry of building Gali Qapu of Isfahan in determining the geometric relationship with Naghsh Jahan square," Indian J. Fundam. Appl. Life Sci., vol. 5, no. S1, pp. 515-524, 2015.

[14] A. Dahar and R. Alipour, "Geometrical Analysis of Architecture of Sheik Lotfollah Mosque to find the Geometrical Relations between its Prayer Hall and the Entrance," Iran. Sci. J. NAZAR Res. Cent. Art, Archit. Urban., vol. 10, no. 26, pp. 33-40, 2013.

[15] R. Jamil, "Role of a Dome-Less Mosque in Conserving the Religious and Traditional Values of Muslims: An Innovative Architecture of Shah Faisal Mosque, Islamabad," Int. J. Archit. Eng. Constr., vol. 6, no. 2, pp. 40-45, 2017.
[16] N. A. Baharudin and A. S. Ismail, "Communal Mosques: Design Functionality towards the Development of Sustainability for Community," Procedia - Soc. Behav. Sci., vol. 153, pp. 10612-, 2014.

[17] M. Livio, The Golden Ratio: The Story of PHI, the World's Most Astonishing Number. New York: Broadway Books, 2002.

[18] M. Akhtaruzzaman and A. A. Shafie, "Geometrical Substantiation of Phi, the Golden Ratio and the Baroque of Nature, Architecture, Design and Engineering," Int. J. Arts, vol. 1, no. 1, pp. 1-22, Aug. 2012.

[19] K. Pavelka, J. Svatušková, and V. Králová, "Photogrammetric Documentation and Visualization of Choli Minaret and Great Citadel in Erbil / Iraq," in XXI International CIPA Symposium, 2007, no. October, pp. 1-6.

[20] A. M. Ali and V. S. Qadir, "The influence of Society's Cultural Aspects on Mosques' Architectural Symbolism: The Mosques built between (1970-1990) in Erbil City as a Case Study," Sulaimani J. Eng. Sci., vol. 2, no. 2, pp. 13-26, 2015. 